\title{
Studies on Lake Erie's littoral algae; Host specificity and temporal periodicity of epiphytic diatoms
}

\author{
David F. Millie' \& Rex L. Lowe ${ }^{2,3}$ \\ 1 Department of Botany, Iowa State University, Ames, IA 50011, U.S.A. \\ 2 Department of Biological Sciences, Bowling Green State University, Bowling Green, OH 43403, U.S.A. \\ ${ }^{3}$ University of Michigan Biological Station, Pellston, MI 49769, U.S.A.
}

Keywords: algae, diatoms, periphyton, Lake Erie, epiphytes, littoral zone

\begin{abstract}
A bstract
Substratum specificity and temporal periodicity of the attached diatom flora upon three aquatic vascular plants and an artificial substratum were examined in three Lake Erie marshes. No qualitative or quantitative specificity for substrata was observed. Variability of diatom assemblage structure within replicate samples of a particular substratum type was as great as, or greater than, variability between substrata. Diatom assemblages upon dowel rod displayed a mid to late summer density maximum. Variability of density maxima upon natural substrata was attributed to different growth rates of the host macrophytes. Diatom assemblages within each sampling site possessed a distinct temporal periodicity indicating that factors affecting diatom growth are heterogeneous in distribution throughout Lake Erie's littoral zone.
\end{abstract}

\section{Introduction}

The epiphytic algal flora plays an important role in shallow freshwater systems (Brock 1970; Allen 1971; Sheldon \& Boylen 1975; Cattaneo \& Kalff 1980). This assemblage is the base of most food webs in the littoral habitat and a source of dissolved and particulate organic matter to the water. Although attached algal assemblages are often the dominant producers in shallow lentic systems, little is known concerning their geographical distributions, population dynamics, and microhabitat utilization (Wetzel 1975).

The question of whether an algal taxon, or group of taxa, is specifically associated with a particular substratum has long intrigued algal ecologists. Several studies (Prowse 1959; Edsbagge 1968; Rautiainen \& Ravenko 1972; Ramm 1977; Eminson \& Moss 1980) reported a definite host specificity by epiphytes. Eminson \& Moss (1980) suggested this to be an expected occurrence due to dynamic bio- logical, physical and chemical properties of macrophytic substrata. Other researchers, however, disputed this theory of specificity (Cholnoky 1927; Fritsch 1931; Simonsen 1962; Main \& McIntire 1974; Hutchinson 1975; McIntire \& Moore 1977), noting that algal distribution is probably a response to physical factors rather than a phenomenon of host specificity. Host macrophytes, therefore, only provide potential surface area for colonization rather than interacting nutritionally with epiphytes (Main \& McIntire 1974).

The western basin of Lake Erie has been the site of extensive phycological research. However, very little information exists concerning the littoral algal flora, especially the diatoms (Millie \& Lowe 1981). The intent of this study is to provide additional qualitative and quantitative information on host macrophyte-epiphytic diat om specificity from three Lake Erie marshes. The composition and temporal periodicity of the epiphytic diatom flora is also reported. 


\section{Materials and methods}

\section{Sampling and counting procedures}

The study was conducted at three marshes located in northwestern Ohio (U.S.A.) along the southern shore of Lake Erie. Sampling locations were established within the Navarre Unit of the Ottawa Wildlife Refuge, Winous Point Shooting Club, and Moxley's Marsh (Fig. 1). Typha angustifolia L., Nymphaea tuberosa Paine, and Polygonum coccineum Muhl, were selected as substrata for epiphytic collections due to their commonness in all marshes. Wooden dowel rod $(0.95 \& 1.11 \mathrm{~cm}$ diameter $)$ was chosen as an artificial substratum. Two or three sampling sites were established within each marsh. Sampling sites within marshes are referred to as:

Navarre Unit \#1 - site containing $N$. tuberosa, $T$. angustifolia, and dowel rod
Navarre Unit $\# 2$ - site containing $P$. coccineum and dowel rod

Winous Point \#1 - site containing $N$. tuberosa and dowel rod

Winous Point \#2 - site containing $P$. coccineum and dowel rod

Winous Point \#3 - site containing $T$. angustifolia and dowel rod

Moxley's Marsh \#1 - site containing $P$. coccineum, T. angustifolia and dowel rod

Moxley's Marsh $\# 2$ - site containing $N$. tuberosa and dowel rod.

Dowel rod was driven into marsh sediments approximately three weeks prior to the first sampling date in order to parallel initial colonization of natural substrata. Epiphytes were collected every three weeks from 10 June 1977 to 7 October 1977. Culms of $T$. angustifolia, stems of $P$. coccineum and petioles of $N$. tuberosa were sampled approximately 15

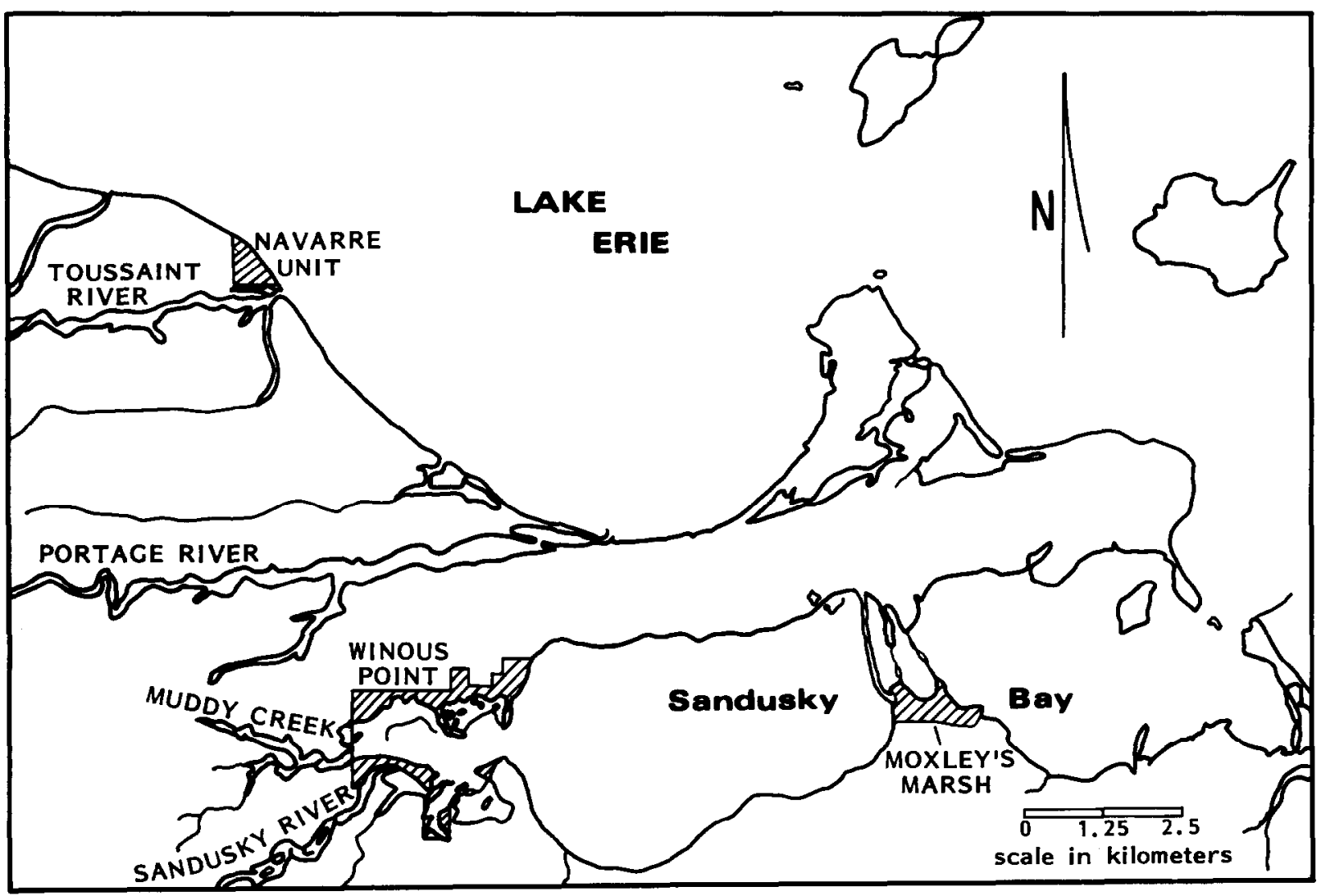

Fig. I. Location of the three Lake Erie marshes utilized for sampling epiphytic assemblages. 
centimeters below the surface of the water to reduce the potential effects of wave action on epiphytic growth. A ten centimeter tube (internal diameter $1.75 \mathrm{~cm}$ ) was used to prevent the loss of a large majority of loosely attached algae. The aerial portion of the macrophyte was cut and the tube slid over the cut culm, stem or petiole. The bottom portion of the macrophyte was cut and the tube sealed. Dowel rod was sampled in a similar manner. Samples were taken in triplicate whenever possible.

Diatoms were removed from the substrata by careful scraping and 'cleaned' by heating in nitric acid. Permanent slides for light microscopy were prepared with Hyrax Mounting Medium (I.R. 1.65). Diatoms were identified and enumerated through horizontal transects of the coverslips under a $100 \times$ apochromatic oil immersion objective $(1.32$ N.A.). Five hundred diatom valves, rather than complete frustules, were counted per slide since the frustules of certain taxa separate more readily than others during the cleaning process (Camburn et al. 1978). Since substrata at each site were usually sampled in triplicate, the vector from which statistical analyses were generated was usually based upon 1500 diatom valves.

\section{Data analysis}

Diatom standing crops were estimated with the formula:

$$
\text { Cells } / \mathrm{mm}^{2}=\left((\text { Valves } / 2)\left(V_{s}\right)\left(V_{c}\right)(A)\right) / A_{\text {sub }}
$$

where $V_{s}$ is the ratio of the original volume of the algal sample to the aliquot of the original volume used in sample preparation, $V_{c}$ is the ratio of the volume of the cleaned diatom sample to the volume of the cleaned sample used in coverslip preparation, $A$ is the ratio of the total area of the coverslip to that area scanned in counting and $A_{\text {sub }}$ is the area of the substrate sampled. Standing crops for each sampling site were compared by a factorial analysis (Snedecor \& Cochran 1980) in terms of substratum type and sampling date.

The similarity of diatom assemblages, in terms of the relative abundance of the taxa, between substrata and between replicate samples of similar substrata, was estimated for each sampling date by Stander's Similarity Index (SIMI) (Stander 1970):

$$
\left.\operatorname{SIMI}(1,2)=\sum_{\mathrm{i}=1}^{\mathrm{T}} \mathrm{N}_{1 \mathrm{i}} \mathrm{N}_{2 \mathrm{i}} / \underset{\mathrm{i}=1}{\sum_{\mathrm{i}}^{\mathrm{T}} \mathrm{N}_{1 \mathrm{i}}{ }^{2}} \underset{\mathrm{i}=1}{\mathrm{~T}} \mathrm{~N}_{2 \mathrm{i}}{ }^{2}\right)^{1 / 2}
$$

where SIMI is the degree of similarity between the assemblages, $\mathrm{N}_{1 \mathrm{i}}$ and $\mathrm{N}_{2 \mathrm{i}}$ are the proportion of individuals represented by the ith taxon in assemblages 1 and 2 respectively, and $T$ is the total number of taxa. SIMI values range from zero to one. As the relative abundance of the common taxa in the two assemblages approach equality, SIMI values approach one. If the two assemblages share no common taxa, the value of zero results. Ninetyfive percent confidence intervals for the calculated SIMI values were estimated using the computer simulation techniques presented by Johnson \& Millie (1982).

Diatom assemblage structure, in terms of percentage of taxa shared between substrata and between replicate samples of similar substrata, was estimated for each sampling date by the Coefficient of Community (Whitaker \& Fairbanks 1958):

$$
\mathrm{CC}=\mathrm{C} /(\mathrm{A}+\mathrm{B}-\mathrm{C})
$$

where $\mathrm{CC}$ is the degree of similarity between the assemblages, $A$ is the number of taxa in the first assemblage, $B$ is the number of taxa in the second assemblage, and $C$ is the number of taxa in both assemblages. Like SIMI, Coefficient of Community values will range from zero to one; one indicating perfect similarity and zero indicating no similarity.

Temporal periodicity of diatom assemblages was estimated by the Succession Rate Index (SRI) proposed by Williams \& Goldman (1975) and modified by Klarer (1978):

$$
\operatorname{SRI}(1,2)=\left(\sum_{i=1}^{T}\left(F_{2}-F_{1} / D\right)^{2}\right)^{1 / 2}
$$

where SRI is the succession rate of taxa per day from one sampling date to the next, $F_{1}$ and $F_{2}$ are weighted logrithmic fractions of total diversity attributable to a single taxon from sampling times 1 and 2 respectively, $D$ is the number of days between sampling date, and $T$ is the total number of taxa. Regression equations were calculated from SRI values for each sampling site. 


\section{Results}

Two hundred and fifty-two diatom taxa encompassing 38 gencra, 12 familics, and 8 orders were identified. Thirty-five percent of all taxa observed were present in all three marshes. Thirteen percent of all taxa were limited to sampling sites within the Navarre Unit. Eleven and nine percent of all the taxa were limited to sampling sites within Winous Point and Moxley's Marsh respectively.

Diatom standing crops varied betwcen substrata within a sampling site, between sampling sites, and between sampling dates (see Millie 1979). Generally, standing crops ranged from $2 \times 10^{3}$ to $4 \times 10^{4}$ cells $/ \mathrm{mm}^{2}$ (Table 1). Diatoms epiphytic upon $P$. coccineum at Navarre unit $\# 2$ on 6 September reached the highest standing crop of any substratum and sampling sitc with $1.2 \times 10^{5} \mathrm{cclls} / \mathrm{mm}^{2}$. Standing crop maxima were also variable between substrata at all sites. Cell density upon dowel rod maximized in mid to late summer. Cell density upon $N$. tuberosa peaked in early to mid summer and decreased throughout the rest of the study period. Standing crops of $P$. coccineum and $T$. angustifolia increased as the study progresscd, maximizing in early fall and late fall respectively.

Table 1. Density values of diatom assemblages epiphytic upon substrata at all sampling locations. Highest and lowest values observed throughout the study are presented. Values represent the mean cell densities of assemblages upon replicate samples within a substratum type. Substrata are referenced as NT = Nymphaea tuberosa, TA $=$ Typha angustifolia, $\mathrm{PC}=$ Polygonum coccineum, and DR $=$ dowel rod.

\begin{tabular}{llc}
\hline Location & Substratum & $\begin{array}{l}\text { Density } \\
\left.\text { (cells } \times 10^{3} \mathrm{~mm}^{2}\right)\end{array}$ \\
\hline Navarre Unit \#1 & DR & $0.6-4.4$ \\
& NT & $0.7-3.7$ \\
Navarre Unit \#2 & TA & $0.5-1.4$ \\
& DR & $5.5-36.5$ \\
Winous Point \#1 & PC & $3.5-120.0$ \\
Winous Point \#2 & DR & $2.0-16.5$ \\
& NT & $1.5-30.5$ \\
Winous Point \#3 & DR & $4.5-21.0$ \\
& PC & 10.5 \\
& DR & $24.5-37.5$ \\
Moxley's Marsh \#1 & TA & $1.5-42.0$ \\
& DR & $4.0-19.6$ \\
& TA & $1.0-10.0$ \\
Moxley's Marsh \#2 & PC & $4.0-9.0$ \\
& DR & $10.5-69.0$ \\
& NT & $4.0-34.5$ \\
\hline
\end{tabular}

Table 2. Results of a factorial analysis performed on diatom densities of different substrata and sampling dates for each sampling location. Levels of significance are: $-=$ no significant difference, $+=$ significance at $0.05,++=$ significance at 0.01 , $+++=$ significance at $0.00 \mathrm{I}$.

\begin{tabular}{llll}
\hline Location & Date & Substratum & Date * Substratum \\
\hline Navarre Unit \#1 & - & ++ & +++ \\
Navarre Unit \#2 & ++ & - & - \\
Winouw Point \#1 & + & - & - \\
Winous Point \#2 & - & - & - \\
Winous Point \#3 & - & - & - \\
Moxley's Marsh \#1 & - & +++ & ++ \\
Moxley's Marsh \#2 & - & - & - \\
\hline
\end{tabular}

A factorial analysis (Table 2) found standing crop in terms of substratum and sampling date to be of variable significance. Navarre Unit $\# 1$ and Winous Point \#1 produced statistically significant differences between standing crops in terms of date. Navarre Unit \#1 and Moxley's Marsh \#1 produced significant standing crop differences in terms of substratum-day interaction. No diatom assemblage at any site exhibited significant substratum specificity throughout the entire study.

Stander's Similarity Index values (SIMI) with their simulated confidence intervals and the Coefficient of Community values for comparison of assemblages epiphytic upon different substrata are presented in Tables 3 through 5. The highest SIMI value approached total equality with a value of 0.99 (Tables 4 \& 5). The highest SIMI value obtained in comparisons of assemblages upon natural substrata was 0.98 (Tables $3 \&$ 5). The lowest SIMI value obtained was 0.72 (Table 4). Coefficient of Community values ranged from 0.15 to 0.72 . For the most part, coefficient values at all sites ranged from 0.4 to 0.6. Moxley’s Marsh $\# 2$ possessed the lowest values ranging from 0.15 to 0.40 .

The range of SIMI and Coefficient of Community values computed for comparisons of diatom assemblages of replicate samples within a substratum type throughout the entire study are presented in Table 6. SIMI values computed for replicate samples within substratum types were very similar to values computed for comparisons between substratum types. The range of Coefficient of Community values for replicate samples within a substratum type, however, was generally lower than values computed for comparisons between substrata. 
Each sampling site within a marsh was characterized by a distinct diatom assemblage (Millie 1979). Navarre Unit \#1 possessed no real dominant taxa at the beginning of the study; Nitzschia palea (Kütz.) W. Sm. and $N$. fonticola Grun. being the most abundant forms. By fall, Navicula sp., N. cryptocephala Kütz., and Nitzschia palea had become the dominant taxa. Navarre Unit $\# 2$ displayed a more distinctive shift in species composition with Nitzschia capitellata Hust., Gomphonema parvulum Kütz., and Stephanodiscus subtilis (Van Goor) A. Cleve being the most abundant taxa in early summer. Melosira distans var. alpigena Grun. and Cyclotella meneghiniana Kütz. became the dominant forms by August. Nitzschia filiformis (W. Sm.) Hust. and $N$. fonticola were the dominant taxa in the fall. Winous Point \#1 possessed an assemblage dominated by the centric diatoms Stephanodiscus minutus Grun. ex Cleve \& Moll, Stephanodiscus subtilis, and Cyclotella meneghiniana, until the last sampling date when Navicula tripunc- tata var. schizonemoides (V.H.) Patr. exhibited a relative abundance ranging from 39 to $61 \%$. Winous Point \#3 showed a similar shift in taxa as Navicula mutica var. undulata (Hilse) Grun. became the most abundant on 7 October. Stephanodiscus subtilis, C. meneghiniana, and Nitszchia palea had previously been the dominant taxa throughout the summer and early fall. Winous Point $\# 2$ showed little change throughout the study as the centrics, $S$. subtilis, C. meneghiniana, and the keel-pennate forms, Nitzschia palea and $N$. capitellata, dominated the assemblage on all sampling dates. Nitzschia parvula var. terricola Lund appeared to exhibit some substrate specificity, as, on 7 October, a high relative abundance of this taxon was observed only upon dowel rod. Moxley's Marsh \#1 was characterized by a distinct shift in taxa. The early summer dominants Achnanthes minutissima Kütz. and Gomphonema parvulum gave way to a fall assemblage dominated by Nitzschia amphibia Grun. and $N$. frustulum var. perpu-

Table 3. Stander's Similarity Index (SIMI) and Coefficient of Community values for comparison of diatom assemblages epiphytic upon substrata at sampling sites within the Navarre Unit of the Ottawa Wildlife Refuge. Nine-five percent confidence intervals for SIMI values are presented in parentheses. Substrata are referenced as: $\mathrm{NT}=$ Nymphaea tuberosa, $\mathrm{TA}=$ Typha angustifolia, $\mathrm{PC}=$ Polygonum coccineum, and DR = dowel rod.

\begin{tabular}{|c|c|c|c|c|c|}
\hline \multirow[t]{2}{*}{$\begin{array}{l}\text { Navarre Unit \#1 } \\
\text { Sampling date }\end{array}$} & \multirow[t]{2}{*}{ Substratum } & \multicolumn{2}{|l|}{ SIMI } & \multicolumn{2}{|c|}{ Coeff. of Comm. } \\
\hline & & Substratum & $\mathrm{DR}$ & Substratum & DR \\
\hline \multirow[t]{2}{*}{10 June 1977} & $\mathrm{NT}$ & $0.89(0.85-0.93)$ & $0.80(0.74-0.86)$ & 0.50 & 0.53 \\
\hline & TA & & $0.86(0.82-0.90)$ & & 0.49 \\
\hline \multirow[t]{2}{*}{2 July 1977} & NT & $0.79(0.72-0.86)$ & $0.89(0.84-0.94)$ & 0.55 & 0.52 \\
\hline & TA & & $0.89(0.87-0.91)$ & & 0.52 \\
\hline \multirow[t]{2}{*}{23 July 1977} & NT & $0.85(0.78-0.92)$ & $0.82(0.76-0.88)$ & 0.67 & 0.66 \\
\hline & TA & & $0.84(0.79-0.89)$ & & 0.57 \\
\hline \multirow[t]{2}{*}{13 August 1977} & NT & $0.91(0.86-0.96)$ & $0.74(0.65-0.83)$ & 0.61 & 0.46 \\
\hline & TA & & $0.75(0.66-0.84)$ & & 0.53 \\
\hline \multirow[t]{2}{*}{6 September 1977} & NT & $0.98(0.95-1.00)$ & $0.80(0.720 .88)$ & 0.52 & 0.49 \\
\hline & TA & & $0.76(0.67-0.85)$ & & 0.57 \\
\hline \multirow[t]{2}{*}{7 October 1977} & NT & $0.87(0.82-0.92)$ & $0.88(0.83-0.93)$ & 0.62 & 0.50 \\
\hline & TA & & $0.76(0.68-0.84)$ & & 0.46 \\
\hline \multicolumn{6}{|l|}{ Navarre Unit \#2 } \\
\hline Sampling date & Substratum & \multicolumn{2}{|r|}{ SIMI } & \multicolumn{2}{|c|}{ Coeff. of Comm. } \\
\hline $10 \mathrm{June} 1977$ & PC vs. DR & \multicolumn{2}{|r|}{$0.89(0.85-0.95)$} & \multicolumn{2}{|c|}{0.51} \\
\hline 2 July 1977 & PC vs. DR & \multicolumn{2}{|r|}{$0.84(0.79-0.89)$} & \multicolumn{2}{|c|}{0.57} \\
\hline 23 July 1977 & PC vs. DR & \multicolumn{2}{|r|}{$0.93(0.90-0.96)$} & \multicolumn{2}{|c|}{0.53} \\
\hline 13 August 1977 & PC vs. DR & \multicolumn{2}{|r|}{$0.81(0.75-0.87)$} & \multicolumn{2}{|c|}{0.53} \\
\hline 6 September 1977 & PC vs. DR & \multicolumn{2}{|r|}{$0.78(0.69-0.87)$} & \multicolumn{2}{|c|}{0.44} \\
\hline 7 october 1977 & PC vs. DR & \multicolumn{2}{|r|}{$0.91(0.85-0.97)$} & \multicolumn{2}{|c|}{0.45} \\
\hline
\end{tabular}


silla (Rabh.) Grun. In contrast, Moxley’s Marsh \#2 exhibited little species change as $A$. minutissima dominated all substrates throughout the entire study. A change was observed in the less abundant taxa as G. parvulum was replaced by Nitzschia fonticola, $N$. filiformis, and $N$. palea.

Succession rates for each sampling site are presented in Figs. 2 and 3. Linear regression equations for each set of computed SRI values accompany corresponding graphs. These regression equations were not meant for the application of any statistical model to SRI values, but used only to indicate 'trends' of the SRI values for the time intervals (Jassby \& Goldman 1974). Correlation coefficients between SRI and time values for Navarre Unit \#1 and $\# 2$, Winous Point $\# 1, \# 2$, and \#3, and Moxley's Marsh \#1 and \#2 were -0.916 and $-0.150,-0.901$, -0.960 and -0.835 , and -0.906 and -0.648 respectively.

Each sampling site possessed a distinct pattern in the successional rate of its taxa. In almost all sites, the successional rate decreased throughout the entire study. Winous Point \#1 possessed a decreasing successional rate from $10 \mathrm{June}$ to $6 \mathrm{September}$. The rate then increased greatly for the time interval of 6 September to 7 October. Due to the large increase in rate for only this one time interval, the regression equation presented for this site only includes values from 10 June to 6 September (see below). Navarre Unit $\# 2$ possessed the most variable succession rate with no real increasing or decreasing 'trend' indicated by the computed SRI values. The regression equation for this site also indicated no distinct temporal pattern.

\section{Discussion}

Diatom assemblages colonizing different macrophytes and dowel rod were not structurally differ-

Table 4. Stander's Similarity Index (SIMI) and Coefficient of Community values for comparison of diatom assemblages epiphytic upon substrata at sampling sites within Winous Point Shooting Club. Ninety-five percent confidence intervals for SIMI values are presented in parentheses. Substrata are referenced as: NT - Nymphaea tuberosa, TA $=$ Typha angustifolia, $\mathrm{PC}=$ Polygonum coccineum, and DR $=$ dowel rod.

\begin{tabular}{|c|c|c|c|}
\hline $\begin{array}{l}\text { Winous Point \#1 } \\
\text { Sampling date }\end{array}$ & Substratum & SIMI & Coeff. of Comm. \\
\hline 10 June 1977 & NT vs. DR & $0.96(0.92 \quad 1.00)$ & 0.41 \\
\hline 2 July 1977 & NT vs. DR & $0.92(0.88-0.96)$ & 0.49 \\
\hline 23 July 1977 & NT vs. DR & $0.85(0.76-0.94)$ & 0.50 \\
\hline 13 August 1977 & NT vs. DR & $0.93(0.90-0.96)$ & 0.42 \\
\hline 6 September 1977 & NT vs. DR & $0.96(0.94-0.98)$ & 0.47 \\
\hline 7 October 1977 & NT vs. DR & $0.93(0.90-0.96)$ & 0.37 \\
\hline $\begin{array}{l}\text { Winous Point \#2 } \\
\text { Sampling date }\end{array}$ & \multicolumn{3}{|c|}{ Winous Point \#2 } \\
\hline 10 June 1977 & PC vs. DR & $0.96(0.93-0.99)$ & 0.59 \\
\hline 2 July 1977 & PC vs. DR & - & - \\
\hline 23 July 1977 & PC vs. DR & $0.93(0.87-0.99)$ & 0.54 \\
\hline 13 August 1977 & PC vs. DR & $0.94(0.90-0.97)$ & 0.49 \\
\hline 6 September 1977 & PC vs. DR & - & - \\
\hline 7 October 1977 & PC vs. DR & $0.77(0.70-0.84)$ & 0.47 \\
\hline \multicolumn{4}{|l|}{ Winous Point $\# 3$} \\
\hline Sampling date & Substratum & SIMI & Coeff. of Comm. \\
\hline 10 June 1977 & TA vs. DR & - & - \\
\hline 2 July 1977 & TA vs. DR & $0.92(0.84-1.00)$ & 0.49 \\
\hline 23 July 1977 & TA vs. DR & $0.99(0.97-1.00)$ & 0.42 \\
\hline 13 August 1977 & TA vs. DR & $0.89(0.83-0.95)$ & 0.48 \\
\hline 6 September 1977 & TA vs. DR & $0.72(0.64-0.80)$ & 0.41 \\
\hline 7 October 1977 & TA vs. DR & $0.94(0.91-0.97)$ & 0.50 \\
\hline
\end{tabular}


Table 5. Stander's Similarity Index (SIMI) and Coefficient of Community values for comparison of diatom assemblages epiphytic upon substrata at sampling sites within Moxley's Marsh. Ninety-five percent confidence intervals for SIMI values are presented in parentheses. Substrata are referenced as: $\mathrm{NT}=$ Nymphaea tuberosa, $\mathrm{TA}=$ Typha angustifolia, $\mathrm{PC}=$ Polygonum coccineum, and $\mathrm{DR}=$ dowel rod.

\begin{tabular}{|c|c|c|c|c|c|}
\hline \multirow[t]{2}{*}{$\begin{array}{l}\text { Moxley's Marsh \#1 } \\
\text { Sampling date }\end{array}$} & \multirow[t]{2}{*}{ Substratum } & \multicolumn{2}{|l|}{ SIMI } & \multicolumn{2}{|c|}{ Coeff. of Comm. } \\
\hline & & $\begin{array}{l}\text { Substratum } \\
\text { PC }\end{array}$ & DR & $\begin{array}{l}\text { Subs } \\
\text { PC }\end{array}$ & DR \\
\hline \multirow[t]{2}{*}{10 June 1977} & $\mathrm{TA}$ & $0.98(0.96-1.00)$ & $0.90(0.86-0.94)$ & 0.56 & 0.72 \\
\hline & $\mathrm{PC}$ & & $0.92(0.89-0.95)$ & & 0.64 \\
\hline \multirow[t]{2}{*}{2 July 1977} & $\mathrm{TA}$ & $0.88(0.83-0.93)$ & $0.88(0.83-0.93)$ & 0.55 & 0.57 \\
\hline & PC & & $0.79(0.71-0.87)$ & & 0.59 \\
\hline \multirow[t]{2}{*}{23 July 1977} & $\mathrm{TA}$ & $0.85(0.80-0.90)$ & $0.85(0.78-0.92)$ & 0.63 & 0.58 \\
\hline & $\mathrm{PC}$ & & $0.85(0.78-0.92)$ & & 0.54 \\
\hline \multirow[t]{2}{*}{13 August 1977} & TA & $0.96(0.94-0.98)$ & $0.97(0.95-0.99)$ & 0.48 & 0.51 \\
\hline & $\mathbf{P C}$ & & $0.96(0.94-0.98)$ & & 0.50 \\
\hline \multirow[t]{2}{*}{6 September 1977} & $\mathrm{TA}$ & $0.92(0.88-0.96)$ & $0.90(0.86-0.94)$ & 0.58 & 0.51 \\
\hline & $\mathrm{PC}$ & & $0.94(0.91-0.97)$ & & 0.60 \\
\hline \multirow{2}{*}{7 October 1977} & $\mathrm{TA}$ & $0.94(0.91-0.97)$ & $0.87(0.81-0.93)$ & 0.57 & 0.42 \\
\hline & $\mathrm{PC}$ & & $0.98(0.84-0.94)$ & & \\
\hline \multicolumn{6}{|l|}{ Moxley’s Marsh \#2 } \\
\hline Sampling date & Substratum & \multicolumn{2}{|r|}{ SIMI } & \multicolumn{2}{|c|}{ Coeff. of Comm. } \\
\hline $10 \mathrm{~J}$ une 1977 & NT vs. DR & \multicolumn{2}{|r|}{$0.99(0.98-1.00)$} & \multicolumn{2}{|c|}{0.30} \\
\hline 2 July 1977 & NT vs. DR & \multicolumn{2}{|r|}{$0.96(0.93-0.99)$} & \multicolumn{2}{|c|}{0.22} \\
\hline 23 July 1977 & NT vs. DR & \multicolumn{2}{|r|}{$0.93(0.90-0.96)$} & \multicolumn{2}{|c|}{0.26} \\
\hline 13 August 1977 & NT vs. DR & \multicolumn{2}{|r|}{$0.88(0.83-0.93)$} & \multicolumn{2}{|c|}{0.15} \\
\hline 6 September 1977 & NT vs. DR & \multicolumn{2}{|r|}{$0.79(0.70-0.88)$} & \multicolumn{2}{|c|}{0.40} \\
\hline 7 October 1977 & NT vs. DR & \multicolumn{2}{|r|}{$0.93(0.90-0.96)$} & \multicolumn{2}{|c|}{0.29} \\
\hline
\end{tabular}

Table 6. Stander's Similarity Index (SIMI) and Coefficient of Community values for comparison of diatom assemblages of replicate samples within a substratum type. Highest and lowest values observed throughout the entire study are presented.

\begin{tabular}{llll}
\hline Location & Substratum & SIMI & Coeff. of Comm. \\
\hline Navarre Unit - Ottawa & & & \\
Wildlife Refuge & Nymphaea & $0.75-0.94$ & $0.40-0.60$ \\
& $\begin{array}{l}\text { Typha } \\
\text { Polygonum }\end{array}$ & $0.71-0.97$ & $0.47-0.63$ \\
& Dowel Rod & $0.77-0.92$ & $0.42-0.67$ \\
& & & \\
Winous Point & & & \\
Shooting Club & Nymphaea & $0.68-0.99$ & $0.37-0.55$ \\
& Typha & $0.77-0.98$ & $0.39-0.59$ \\
& Polygonum & $0.76-0.97$ & $0.37-0.65$ \\
& Dowel Rod & - & - \\
& & & \\
Moxley's Marsh & Nymphaea & $0.50-0.99$ & $0.29-0.55$ \\
& Typha & $0.72-0.98$ & $0.36-0.61$ \\
& Polygonum & $0.80-0.97$ & $0.37-0.60$ \\
& Dowel Rod & $0.85-0.97$ & $0.51-0.57$ \\
\hline
\end{tabular}

ent. Variability of diatom assemblages within a substratum type was a great as, or greater than, variability of assemblages between substrata. This qualitative and quantitative similarity of assemblages agreed with Simonson's (1962) hypothesis that diatom colonization is random.

The structure of diatom assemblages within and between substratum types was analyzed by Stander's Similarity Index and Coefficient of Community. The similarity index of assemblages between substrata was consistently greater than 0.80 . Although 0.72 was the lowest index computed, this value is still rather high in similarity on the basis of the index scale of zero to one. The interpretation of SIMI, however, is highly variable between studies. Since no specific limitation can be made concerning the degree of similarity, only a general assumption can be implied. The $95 \%$ confidence intervals, therefore, presented a more realistic range of the structural similarity between the two assemblages (Johnson \& Millie 1982). 


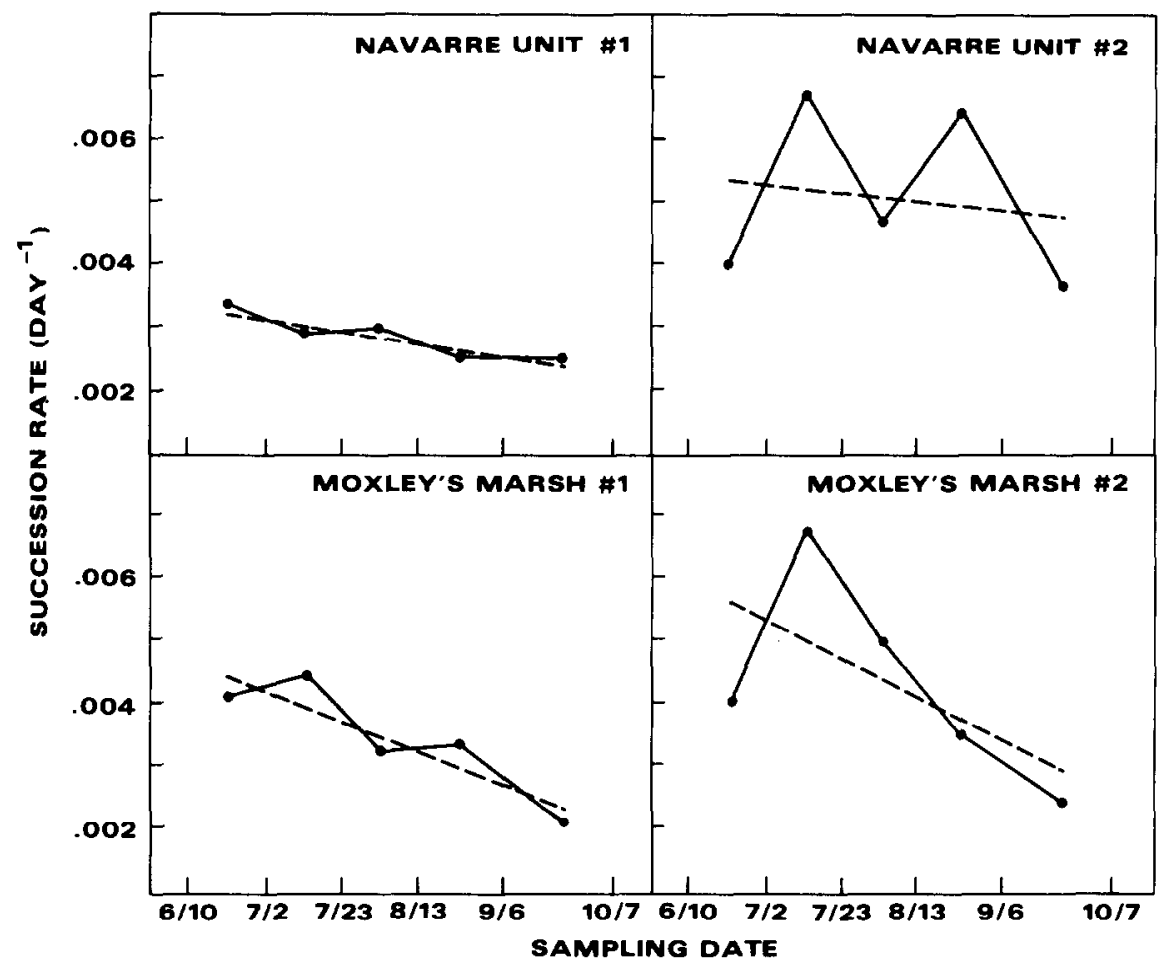

Fig. 2. Succession rates of epiphytic assemblages in sampling sites within the Navarre Unit of the Ottawa Wildlife Refuge and Moxley's Marsh. SRI values are plotted in the middle of the time interval for which they were calculated. Dashed lines represent linear regression equations calculated from SRI values.

Coefficient of Community values were much lower than SIMI values, thereby signifying dissimilarity. However, the coefficient value, while measuring the presence or absence of diatom taxa, is significantly altered by the presence of several 'rare' taxa. Since each substratum possessed a few taxa with a relative abundance of only a few cells, most comparisons produced values ranging from 0.40 to 0.60 . Assemblages which possessed only a few dominant taxa yielded very low coefficient values due to the presence of the rarer taxa differing greatly between samples. For example, substrata at Moxley's Marsh \#2 were dominated by Achnanthes minutissima throughout the study. Comparisons of epiphytic assemblages within this sitc produced cxtremely low coefficient values. The presence of the rare taxa with low relative abundance actually has little effect on the overall structure of the diatom assemblage. Unless pertubation allowed a competitive advantage to a particular taxon, or group of taxa, the presence of the rare taxa would be con- stantly changing with repcated invasion and ensuing competition. Therefore, it is felt that SIMI, rather than Coefficient of Community, produced a more realistic comparison of epiphytic assemblages.

Total cell densities of diatom assemblages upon substrata were extremely variable (Millie 1979). This variability was illustrated by significant interaction valucs of the factorial analysis at Navarre Unit \#1 and Moxley's Marsh \#1. Previous studies (Humm 1964; Klarer \& Hickman 1975; Sullivan 1977) have indicated that maximum epiphytic density will occur in mid to late summer. This expected mid to late summer maxima was displayed only by assemblages upon dowel rod. The variability of standing crop maxima upon natural substrata was attributed to the different growth rates of the host macrophytes. The artificial substratum displayed no change in surface area available for colonization. Vascular substrata displayed different growth rates, and thus, surface area through time. Epiphytic colonization rates, therefore, would be expected 
to differ between macrophytes. The factorial analysis, however, indicated that no particular substratum possessed a significantly different diatom density throughout the entire study.

A lack of quantitative information on epiphytic

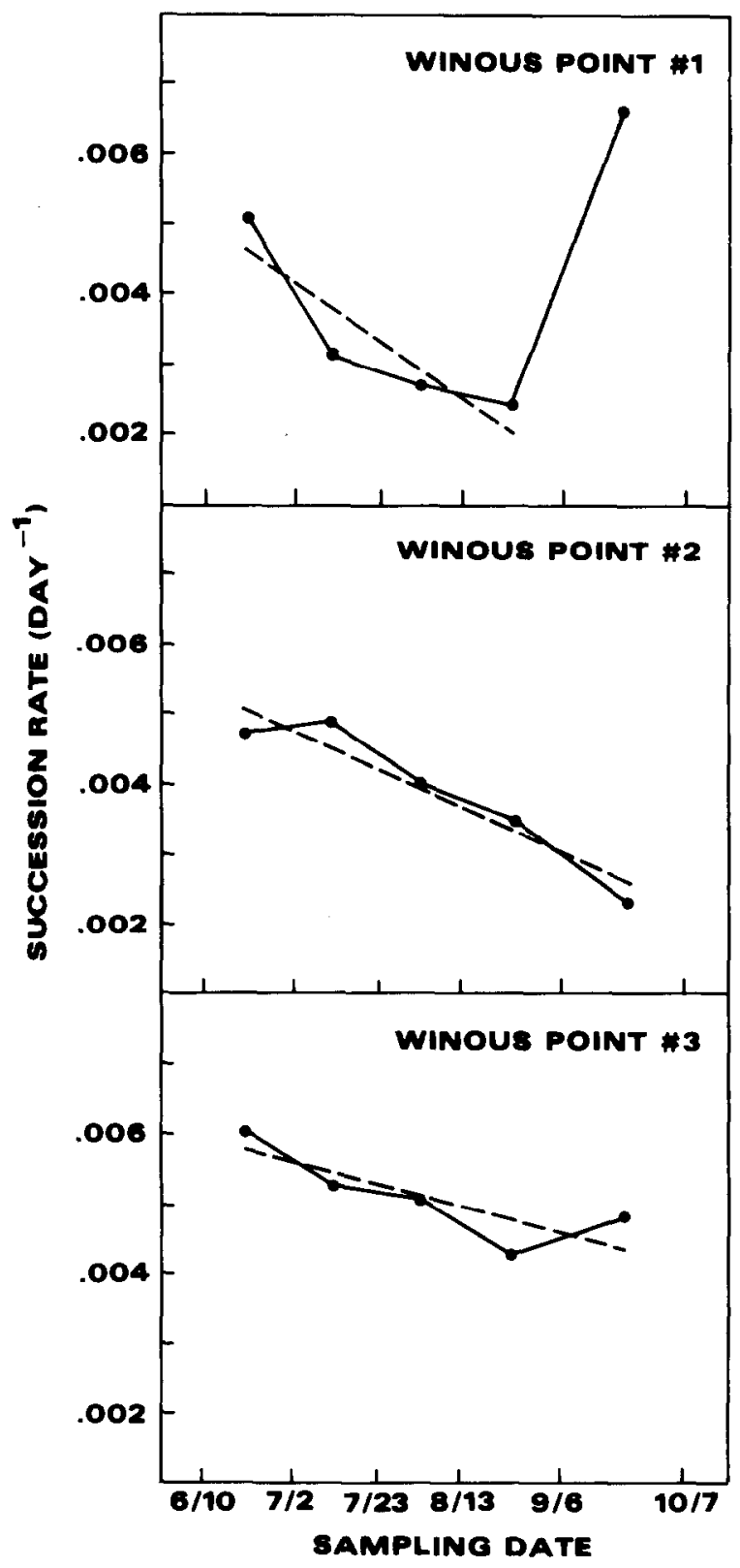

Fig. 3. Succession rates of epiphytic assemblages in sampling sites within Winous Point Shooting Club. SRI values are plotted in the middle of the time interval for which they were calculated. Dashed lines represent linear regression equations calculated from SRI values. algae exists as a result of the difficulty in obtaining consistent samples, removal of the algae from the substrata, and the difficulty in calculating substratum area (A.P.H.A. et al. 1971; Hickman 1971; Main 1973). The standing crop values presented here are considerably lower than values presented by Klarer \& Hickman (1975) and Siver (1977). This discrepancy might be accounted for by the aforementioned problems coupled with the physical, chemical, and biological characteristics peculiar to Lake Erie marshlands. For example, Winous Point $\# 1$, Winous Point $\# 2$, and Navarre Unit \#2 were subject to variable wave action. Fox et al. (1969) noted reduction in total cell numbers and diversity when turbulence made attachment for some taxa difficult. This could have accounted for low standing crops at these sites. In addition, substrata at Winous Point \#2 were subject to periodic exposure due to intense fluctuation in water level in this portion of Sandusky Bay (see Millie 1979). This alternate submergence and dessication could cause low standing crops due to diatom death and subsequent recolonization. This is in contrast to the higher standing crops typically associated with longer periods of colonization.

In analyzing host specificity, factors exist which could cause a misinterpretation of results. In this study, only comparisons of substrata within sampling sites were made to remove geographical and ecological biases. For specificity studies, pure stands of macrophytes should not be compared directly as each stand is not necessarily growing under similar environmental conditions. Only those plants which are intermingled within a common bed of vegetation are suitable for comparisons as environmental factors can then be considered similar (K recker 1939). However, even within a mixed bed of macrophytes, environmental conditions, such as differential shading, can cause the development of many distinct microhabitats. In addition, substratum affinity by epiphytic taxa may appear to exist as a result of differential grazing and/or interspecific competition (Main 1973). Several studies have demonstrated changes in epiphytic assemblages through differential grazing (Dickman 1968; Allanson 1973; Patrick 1978). Round (1960) suggested that competition for nutrients could limit the number of larger periphytic taxa with slow cell division rates. This could have accounted for the extreme abundance of small pennate taxa within the epiphyton (Millie 1979). 
Temporal periodicity was measured by the Succession Rate Index. This index was originally developed to utilize algal biomass in determining succession(Jassby \& Goldman 1974; Williams \& Goldman 1975). Klarer (1978) and this study, however, utilized cell numbers in place of biomass. Diatom taxa with large biomass were rare among the epiphyton. If biomass had been utilized for determination of succession rate, larger rare taxa would be overemphasized while smaller more abundant taxa would be underemphasized. Thus, in conditions where small taxa dominate the assemblage, cell numbers present a more realistic interpretation of the succession rate (Klarer 1978). In addition, since no specificity for substrata by epiphytes was observed, cell counts for all substrata within a sampling site were pooled for each sampling date. Subsequent comparisons between sampling dates for each site utilized this pooled data.

Successional patterns in diatom assemblages were variable between sampling sites indicating the factors dictating succession in Lake Erie's littoral zone to be heterogeneous in distribution. This discontinuity caused the establishment of many unique diatom assemblages throughout the littoral area. Regression equations of SRI values indicated a decreasing trend in the succession rate of taxa at most sampling sites. Epiphytic assemblages, therefore, became more stable as the study progressed.

Navarre Unit \#2 and Winous Point \#1 possessed the greatest fluctuations in succession rates. The extremely low correlation coefficient between SRI and time values at Navarre Unit $\# 2$ indicated no overall increase or decrease in succession rate. The large increase in succession rate for only the last time interval at Winous Point \#l was due to the sudden emergence of Navicula tripunctata var. schizonemoides (V.H.) Patr. as a dominant taxon (Millie 1979; Millie \& Wee 1981). If the regression equation had been calculated with the final SRI value included, an erroneous increasing successional trend for the entire study would have been indicated. Therefore, the exclusion of the last SRI value in calculating the regression equation at this site is justified.

The information presented here by no means completely lays to rest the question of whether macrophytic specificity by epiphytes exist. Although not observed in any of the marshes analyzed here, it is feasible that specificity by epiphytes does occur in nature. If an epiphytic taxon would evolve a physical and/or nutritional specificity for a particular type of substratum, it would be expected to occur in systems which possess stable physical and chemical conditions. Marine and oligotrophic freshwater systems, for the most part, possess more consistent physical and chemical parameters than instable eutrophic freshwater systems, such as Lake Erie. Therefore, the lack of host specificity by epiphytes from the system studied here is not unexpected.

\section{Summary}

1. Epiphytic diatom assemblages were not structurally different between substrata. Variability of diatom assemblages within replicate samples of a particular substratum was as great as, or grcater than, variability between substrata.

2. Stander's Similarity Index produced a more realistic comparison of epiphytic assemblages than did Coefficient of Community.

3. Diatom standing crops upon différent substrata were not significantly different within a sampling site throughout the entirc study.

4. Diatom assemblages upon dowel rod displayed an expected mid to late summer density maximum at all sites. The variability of density maxima observed upon natural substrata was attributed to different growth rates of the host macrophytes.

5. The discrepancy between the range of standing crop values presented and other published literature was attributed to problems in obtaining accurate samples from epiphytic assemblages and characteristics endemic to the sampling sites investigated.

6. Each sampling site possessed a distinct diatom flora and succcssional pattern illustrating the heterogeneity of Lake Erie's littoral habitat.

\section{Acknowledgements}

The authors wish to express their thanks to the United States Fish and Wildlife Service, Winous Point Shooting Club, and Edward Moxley for allowing use of their marshlands. We thank Bruce E. Johnson, Bowling Green State University, and Timothy J. Bliss, Iowa State University for assistance 
in computer programming. D.F.M. is especially indebted to Dr. James H. Peck, University of Arkansas, Karen I. Getman and Dr. James L. Wee, Iowa State University, Dr. John C. Kingston, University of Minnesota at Deluth, and Dr. David $M$. Klarer, Ohio Department of Natural Resources for their advice and encouragement.

This research was supported, in part, by grants from the Graduate College, Bowling Green State University, Bowling Green, Ohio 43403 and the Graduate College, Iowa State University, Ames, Iowa 50011.

\section{References}

Allen, H. L., 1971. Primary productivity, chemo-organotrophy, and nutritional interactions of epiphytic algae and bacteria on macrophytes in the littoral of a lake. Ecol. Monogr. 41: 97-127.

Allanson, B. R., 1973. The fine structure of the periphyton of Chara sp. and Potamogeton natans from Wytham Pond, Oxford, and its significance to the macrophyte-periphyton metabolic model of R. B. Wetzel and H. L. Allen. Freshwat. Biol. 3: 535-542.

American Public Health Association, American Water Works Association \& Water Pollution Control Federation, 1971. Standard methods for the examination of water and wastewater. 13th ed. Am. Public Health Assoc. New York. 874 pp.

Brock, T. D., 1970. Photosynthesis by algal epiphytes of U tricularia in Everglades National Park. Bull. mar. Sci. 20: 952-956.

Camburn, K. E., Lowe, R. L. \& Stoneburner, D. L., 1978. The haptobenthic diatom flora of Long Branch Creek, South Carolina. Nova Hedwigia 30: 149-279.

Cattaneo, A. \& Kalff, J., 1980. The relative contribution of aquatic macrophytes and their epiphytes to the production of macrophyte bed. Limnol. Oceanogr. 25: 280-289.

Cholnoky, B. J., 1927. Untersuchungen uber die Oekologie der Epiphyton. Arch. Hydrobiol. 18: 661-705.

Dickman, M., 1968. The effect of grazing by tadpoles on the structure of a periphyton community. Ecology 49: 1188-1190.

Edsbagge, H., 1968. Some problems in the relationship between diatoms and seaweeds. Botanica mar. 11: 64-67.

Eminson, D. \& Moss, B., 1980. The composition and ecology of periphyton communities in freshwaters. 1 . The influence of host type and external environment on community composition. Br. phycol. J. 15: 429-446.

Fox, J. L., Odlaug, T. O. \& Olsson, T. A., 1969. The ecology of periphyton in western Lake Superior; Part I. Taxonomy and distribution. Wat. Res. Cen. Univ. Minn. Minneapolis. 127 pp.

Fritsch, F. E., 1931. Some aspects of the ecology of freshwater algae (with special reference to static waters). J. Ecol. 19: 233-272.
Hickman, M., 1971. The standing crop and primary productivity of the epiphyton attached to Equisetum fluviatile $\mathbf{L}$. in Priddy Pool, North Somerset. Br. phycol. J. 6: 51-59.

Humm, H. J., 1964. Epiphytes of the sea grass Thalassia testudinum in Florida. Bull. mar. Sci. 14: 306-341.

Hutchinson, G. E., 1975. A treatise on limnology, III. Limnological botany. John Wiley \& Sons, Inc., N.Y. 660 pp.

Jasby, A. D. \& Goldman, C. R., 1974. A quantitative measure of succession rate and its application to the phytoplankton of lakes. Am. Nat. 108: 688-693.

Johnson, B. E. \& Millie, D. F., 1982. The estimation and applicability of confidence intervals for Stander's similarity index (SIMI) in algal assemblage comparisons. Hydrobiologia 89: 3-8.

Klarer, D. M., 1978. Some studies on the plankton of the Dubh Lochan. Ph.D. thesis, Univ. Glasgow, Glasgow. 217 pp.

Klarer, D. M. \& Hickman, M., 1975. The effect of thermal effluent upon the standing crop of an epiphytic algal community. Int. Revue ges. Hydrobiol. 60: 17-62.

Krecker, F. H., 1939. A comparative study of the animal population of certain submerged plants. Ecology 20: 553-562.

Main, S. P., 1973. The distribution of epiphytic diatoms in Yaquina Estuary, Oregon. Ph.D. thesis, Oregon State Univ., Corvallis. $111 \mathrm{pp}$.

Main, S. P. \& McIntire, C. D., 1974. The distribution of epiphytic diatoms in Yaquina Estuary, Oregon (U.S.A.). Botanica mar. 17: 88-99.

McIntire, C. D.\& Moore, W. W., 1977. Marine littoral diatoms; ecological considerations. In: Werner, D. (ed.) The biology of diatoms. Univ. Cal. Press, Berkeley, pp. 333-371.

Millie, D. F., 1979. The epiphytic diatom flora of three species of aquatic vascular plants common to three Lake Erie marshes. M.Sc. thesis, Bowling Green State Univ., Bowling Green, Ohio. 205 pp.

Millie, D. F. \& Lowe, R. L., 1981. Diatoms new to Ohio and the Laurentian Great Lakes. Ohio J. Sci. 81: 195-206.

Millie, D. F. \& Wee, J. L., 1981. Observations on the tube-dwelling diatom Navicula tripunctata var. schizonemoides (V.H.) Patr. using light and electron microscopy. Proc. Iowa Acad. Sci. 88: 74-78.

Patrick, R., 1978. Effects of trace metals in the aquatic ecosystem. Am. Scient. 66: 185-191.

Prowse, G. A., 1959. Relationships between epiphytic algal species and their macrophytic hosts. Nature 183: 1204-1205.

Ramm, G., 1977. Structure of epiphytic diatom populations of the Phytal of the Kiel Bight (Western Baltic). Nova Hedwegia 54: 379-387.

Rautiainen, H.\& Ravenko, O., 1972. The epiphytic diatom flora of the benthic macrophyte communities on rocky shores in the southwestern Archipelago of Finland, Seili Islands. Nova Hedwegia 23: 827-842.

Round, F. E., 1960. Studies on bottom living algae in some lakes of the English lake district. IV. The seasonal cycles of the Bacillariophyceae. J. Ecol. 48: 529-547.

Sheldon, R. B. \& Boylen, C. W., 1975. Factors affecting the contribution by epiphytic algae to the primary productivity of an oligotrophic freshwater lake. Appl. Microbiol. 30: $657-667$. 
Simonsen, R., 1962. Untersuchungen zur Systematik and Okologie der Bodendiatomeen der westlichen Ostee. Int. Revue ges. Hydrobiol., Systemische Beihefte, I, Akademie Verlag, Berlin. 148 pp.

Siver, P. A., 1977. Comparison of attached diatom communities on natural and artificial substrates. J. Phycol. 13: 402-406.

Snedecor, G. W. \& Cochran, W. G., 1980. Statistical methods. 7th ed. The Iowa State Univ. Press, Ames. 507 pp.

Stander, J. M., 1970. Diversity and similarity of benthic fauna off Oregon. M.Sci. thesis, Oregon State Univ., Corvallis. 72 pp.

Sullivan, M. J., 1977. Structural characteristics of a diatom community epiphytic on Ruppia maritima. Hydrobiologia 53: 81-86.
Wetzel, R. B., 1975. Limnology. W. B. Saunders Company, Philadelphia. 743 pp.

Whittaker, R. \& Fairbanks, C., 1958. A study of the plankton copepod communities in Columbia Basin, southeastern Washington. Ecology 39: 46-65.

Williams, N. J. \& Goldman, C. R., 1975. Succession rates in lake phytoplankton communities. Verh. int. Ver. Limnol. 19: 808-811.

Received 9 October 1981; in revised form 5 July 1982; accepted 26 July 1982. 